\title{
THE GROWTH OF CHOLERA (AND OTHER) BACILLI IN DIRECT SUNLIGHT.
}

\author{
By F. F. WesBrook, John Lucas Walker Student in Pathology, \\ Cambridge University.
}

From the Hygienic Laboratory, Marburg; and the Pathological Laboratory, Cambridge University.

Is a recent paper ${ }^{I} I$ was able to show that the rate of destruction of tetanus bacilli (in cultures in liquid media) varied when exposed to sunlight in the presence of air, according to the relation of the surface area to the volume of the culture. ${ }^{2}$

It was found that when equal volumes of the same culture were so exposed, destruction was more rapid in those of large area.

Other observers had noticed that on exposing plate-cultures to the action of the sunlight, whilst the bacteria on the surface were destroyed, those situated more deeply in the culture medium were still capable of development. ${ }^{3}$ For this reason, Marshall Ward, in his experiments, first poured out his agar-agar plates, and then inoculated them, after they had set, by smearing the surface with bacteria by means of a camel's-hair brush. He was thus able to obtain complete destruction of the bacteria in these cultures, or portions of cultures, which had been acted on by the sunlight.

The growth of colonies in the depth of the medium, after exposure of the plates to direct sunlight, had received several explanations, none of which seemed satisfactory. Thus it had been suggested that the bacteria in the upper parts shaded those situated more deeply, and in this way permitted them to grow. These observations of others, together with those made by myself, led me to think it possible that the harmful action of sunlight was appreciable only at the surface of cultures-in other words, in a region where the oxygen was most abundant. ${ }^{4}$

\footnotetext{
1 "Some of the Effects of Sunlight on Tetanus Cultures," Journ. Path. and Bacteriol., Edin. and London, Nov. 1894.

${ }^{2}$ See also Dieudonné, Arb. a. d. k. Gsudhtsamte., Berl., 1894, bd. ix. s. 537, etc.

${ }^{3}$ Marshall Ward, Proc. Roy. Soc. London, 1893, vol. liii. p. 310 ; and in a lecture given before the Cambridge Philosophical Society, 1894.

${ }^{4}$ Downes and Blunt, Proc. Roy. Soc. London, vol. xxvi. No. 184, Dec. 6, 1877 ; Roux,
} 
In order once more to test this theory, four cultures of the vibrio of Asiatic cholera were made. Each tube contained 10 c.c. of ordinary peptonised beef-broth, and the depth of liquid was the same in all, namely, $9 \mathrm{~cm}$.

The upper part of one tube was enveloped in black paper, so that all of the liquid except the surface and that portion immediately beneath, for a distance of $1 \mathrm{~cm}$., was exposed to the action of the sun (the surface, for a depth of $1 \mathrm{~cm}$., protected, and the lower $8 \mathrm{~cm}$. exposed). The second was covered with black paper, from the bottom to within $1 \mathrm{~cm}$. of the surface (the surface and upper $1 \mathrm{~cm}$. exposed, and lower $8 \mathrm{~cm}$. protected). The third was encircled by black paper, $5 \mathrm{~cm}$. broad, so that a depth of $2 \mathrm{~cm}$. at the surface, and the same at the bottom were left exposed to the sun's rays. The fourth tube was left quite unprotected, and served as a control. All of the tubes were plugged with cotton-wool, and were in every other way ordinary ærobic cultures. Each was inoculated with the same amount (1 wire loop) of a fresh bouillon culture of the comma bacillus. They were then immediately suspended from a glass rod, and placed against a window, through which the brightest summer sun was shining.

A white cotton screen was placed behind them, with its upper border resting against the window above the tubes, so that they were enclosed in a space formed by the window, the screen, and the table on which the screen stood. Curtains at each end of the screen completed the box-like arrangement. A thermometer placed in a testtube of water, and suspended in the same position and manner as the culture tubes, indicated a temperature which varied from $25^{\circ} \mathrm{C}$. to $37^{\circ} \mathrm{C}$., which was higher than elsewhere in the room, the effect of the screen being to raise the temperature of the air between it and the window.

The tubes were exposed in this way for 9 hours, the only change being to move them to another window at noon, so that they might never be out of the direct sunlight.

In using an xrobic micro-organism, like that of cholera, the expectation was that destruction of the bacteria would take place in those cultures in which the surface was exposed to the sun's action, whilst growth would occur in the one tube in which the surface was protected by the black paper.

The cultures were examined at short intervals, and it was noticed at the end of about 5 hours that they had lost their transparency. After 9 hours they were all very markedly turbid. This turbidity was, on microscopic examination, seen to be due to a plentiful and characteristic growth of the vibrio.

Neither on macroscopic nor on microscopic examination could any

Ann. de l'Inst. Pasteur, Paris, 1887, p. 445 ; Momont, Ibid., 1892, vol. vi. p. 21 ; Richardson, Proc. Chem. Soc. London, 1893, p. 121 ; Frankland, "Micro-Organisms in Water," p. 380, etc. ; Dieudonné, op. cit. 
difference be observed in the rate or character of the growth in the four cultures. Abundant growth had taken place in all.

It seemed now necessary to determine the influence of the depth of the medium on this process, and experiments were made with this end in view. ${ }^{1}$

For these experiments the tubes were unprotected by black paper, and the sun was permitted to fall freely on all parts. Clear, nearly colourless, beef-broth or peptone solution was placed in the tubes in depths varying between 1 and $9 \mathrm{~cm}$. Each tube was inoculated with the same amount ( 1 wire loop) of a fresh broth-culture, and immediately all were placed in the window as before.

It will be seen that the tubes containing the small amounts of medium, contained, initially, more bacteria in proportion to the contents; or, in other words, the bacilli were relatively more numerous, as the amount used for inoculation was the same for all.

The tubes were exposed, as before, to continuous sunshine for 9 hours. In those tubes, in which there was a sufficient depth of fluid, growth took place in 4-5 hours, and at the end of 9 hours the turbidity was well marked. In the tubes containing very little broth no growth could be observed at the end of the experiment, nor on keeping in the incubator did any appear.

In the cultures in which the depth of liquid was $2-4 \mathrm{~cm}$., although no turbidity could be observed at the end of the exposure to sunshine, growth appeared later.

It was found possible, then, to draw roughly a line of demarcation between those tubes in which the bacteria would invariably be killed and those in which growth would occur.

In tubes containing a depth of $2 \mathrm{~cm}$. the bacteria were usually completely killed, whilst in those of $1.4 \mathrm{~cm}$, and less, complete destruction took place in every experiment.

On one occasion, one tube, in which the bouillon was $1 \cdot 7 \mathrm{~cm}$. in depth, showed no signs of growth after 9 hours' exposure to the sun, but later a typical growth appeared. In the same experiment the bacteria in a tube, which contained medium to the depth of $1.1 \mathrm{~cm}$., were completely destroyed.

These results were verified by making experiments with cultures in solid media, in which the bacteria were either destroyed or grew in the original position in which they had been placed. Stab-cultures, in clear transparent agar-agar, gave, at the end of 9 hours' exposure to bright sunlight, a well-marked growth along the entire line of puncture, with the exception of that part at the surface.

These cultures resembled in appearance anærobic stab-cultures, and were exposed to the sun for several days in succession, being kept at

${ }^{1}$ In connection with this question see Buchner, Arch. f. Hyg., Muinchen u. Leipzig, 1893 ; Procacei, Ann. d. Ist. d'ig. sper. d. Univ. di Roma, 1893, vol. iii. p. 437 ; Arloing, Arch. de physiol. norm. et path., Paris, 1886, vol. iii. No. 3 ; Frankland, op. cit. 
night in the ice-cupboard, which prevented development between the times of exposure. At the end of the last exposure, though no growth had appeared on the surface, the cultures were placed in a dark incubator, when the growth spread from the needle-track and covered the whole surface.

This would seem to indicate that although the sunlight had been quite capable of preventing any growth on the surface, it had not done so by rendering the culture medium unfit for development. ${ }^{1}$

Cultures made by smearing with cholera the sloped surfaces of nutrient agar-agar were not only prevented from growing by the sunlight's action, but the bacteria were entirely destroyed, so that no growth occurred when they were afterwards incubated in the dark. This was also true of plates made and treated in the same way.

When agar-agar plates were made in the ordinary way, no colonies appeared on the surface, either during the time of exposure to sunlight or later. Those bacteria in the depth of the medium grew as if under ordinary circumstances in the dark incubator.

This was very well shown by inoculating a tube of molten agar, with which a plate was poured. After the plate had set, another tube of molten agar was poured over the surface. Such plates, on being suspended in the same manner as the tubes before described, gave most luxuriant growths in the brightest sunlight.

When it was ascertained beyond all doubt that under certain conditions (i.e. when the liquid medium was of sufficient depth), the vibrio of cholera was capable of growing vigorously, when exposed to strong sunshine in the presence of air, it seemed desirable to know whether the bacteria so grown were affected in regard to virulence. ${ }^{2}$

Freshly-inoculated tubes of broth or peptone solution were hung in the window, in the way before described, for a time varying from 5-9 hours. During the night the cultures were kept in an icecupboard; and on the following morning, from the tube containing the greatest depth of medium (usually $5-9 \mathrm{~cm}$.), a fresh series was inoculated and suspended in the sunshine. This was repeated six times, and during the whole period continuous sunshine prevailed, so that at the conclusion there were obtained vibrios of cholera which had been grown for six generations in the bright sunshine. The temperature registered by the thermometer, hanging in a test-tube of water, and suspended with the cultures, varied usually between

1 See Roux, Ann. de l'Inst. Pasteur, Paris, 1887, vol. i. p. 445 ; Pansini, Riv. d'ig. prat. e sper., Napoli, 1889 ; "Azione della luce solare sui micro-organismi"; Janowski, Centralbl. f. Bakterial. u. Parasitenk., Jena, 1890, bd. viii.; Ward, op. cit. ; Dieudonné, op. cit., p. 405.

2 Against this the objection might be brought forward, that a transference of even very attenuated cultures of the cholera vibrio to fresh agar-agar might have restored their virulence. There seemed, however, no other method in which comparison could be satis. factorily made, since neither ordinarily incubated broth-cultures nor insolated brothcultures developed sufficiently in 9 hours for inoculation experiments.

25-JI. OF PATH.—VOL. III. 
$22^{\circ} \mathrm{C}$. and $35^{\circ} \mathrm{C}$, although on the second day, for about 2 hours, it remained at $41^{\circ} \mathrm{C}$.

The cholera vibrios used for these experiments had been isolated but a few days before from a case of the disease occurring at Bürgeln.

These cholera bacteria, after growing for six generations in the direct sunlight, were transferred to agar-agar, and the virulence compared with similar cultures made from the same cholera which had been kept in the form of broth-cultures in the dark.

The test cultures used for inoculation into animals were grown for 22 hours at a temperature of $37^{\circ} \cdot 5 \mathrm{C}$, on the sloped surface of agaragar (so inoculated that when grown the whole surface was covered).

The whole of the growth was scraped from the surface of the culture and suspended in 10 c.c. of sterile bouillon, and injected into the peritoneal cavities of guinea-pigs as follows :-

\begin{tabular}{|c|c|c|c|c|c|c|c|c|}
\hline \multirow{2}{*}{ No. } & \multirow{2}{*}{$\begin{array}{l}\text { Weight } \\
\text { in } \\
\text { Grms. }\end{array}$} & \multirow{2}{*}{$\begin{array}{c}\text { Dose of } \\
\text { Suspension. }\end{array}$} & \multirow{2}{*}{$\begin{array}{l}\text { Material } \\
\text { Injected. }\end{array}$} & \multicolumn{4}{|c|}{ Temperature. } & \multirow{2}{*}{ Remarks. } \\
\hline & & & & $12 \mathrm{~A} . \mathrm{M}$. & 2 P.M. & 4 P.M. & 7 P.M. & \\
\hline 1 & 600 & 1 c.e. & $\begin{array}{l}\text { Cholera, } \\
\text { which had } \\
\text { been kept } \\
\text { and grown } \\
\text { in dalk. }\end{array}$ & $\begin{array}{l}\approx \\
0 \\
-1\end{array}$ & $40 \cdot 0$ & $39 \cdot 3$ & $36 \cdot 5$ & $\begin{array}{l}\text { Dead next } \\
\text { morning. }\end{array}$ \\
\hline 2 & 545 & 2 c.c. & $"$ & $\stackrel{+}{-}$ & $39 \cdot 1$ & $39 \cdot 7$ & $34 \cdot 3$ & ", \\
\hline 3 & 460 & 3 c.e. & , & 0 & 39.4 & $37 \cdot 3$ & $34 \cdot 5$ & , \\
\hline 4 & 665 & 1 c.c. & $\begin{array}{l}\text { Cholera, } \\
\text { which had } \\
\text { grown for } \\
\text { six genera- } \\
\text { tions in } \\
\text { sunlight. }\end{array}$ & $\begin{array}{l}a \\
\sim \\
\overrightarrow{0} \\
\therefore \\
\therefore\end{array}$ & $39 \cdot 8$ & $39 \cdot 2$ & $37 \cdot 8$ & $\begin{array}{l}\text { Very ill } \\
\text { next mor- } \\
\text { ning ; died } \\
29 \text { hours } \\
\text { after inocu- } \\
\text { lation. }\end{array}$ \\
\hline 5 & 595 & 2 c.c. & $"$ & $\begin{array}{l}0 \\
0 \\
0\end{array}$ & $39 \cdot 5$ & $39 \cdot 1$ & 36.8 & $\begin{array}{l}\text { Dead next } \\
\text { morning. }\end{array}$ \\
\hline 6 & 475 & 3 c.c. & ", & & $37 \cdot 5$ & $37 \cdot 4$ & $34: 8$ & " \\
\hline
\end{tabular}

As will be seen by the foregoing table, there was very little, if any, decrease ${ }^{1}$ in the virulence of those cultures which had been grown in sunlight for six generations. The animal which survived longest was the largest of the series, and he died within 30 hours after inoculation of so small a dose as one-tenth of a culture.

Although no exhaustive experiments were made, it was found that Bacilli prodigiosus, $B$. typhi, and $B$. coli communis grow quite well in sunlight, and they were found to behave in the same way as the

1 Palermo working differently, i.e. exposing fully-grown cultures for a few hours only, obtained evidence of attenuation; Ann. d. Ist. d'ig. sper. d. Univ. di Roma, 1893, vol. iii. p. 463. 
comma bacillus, developing quite vigorously at the end of 9 hours, when in a depth of liquid of $5 \mathrm{~cm}$, and at a temperature of $25^{\circ}$ C. $-37^{\circ}$ C. $B$. prodigiosus, ${ }^{1}$ under these circumstances and at this temperature, did not form any colour, though this appeared later when left in the light of an ordinary room for a few days at the room temperature. No experiments were made to determine whether the virulence was affected or not in these cultures.

As might be expected from these experiments, and those mentioned in a former paper, it was found that cultures of the $B$. tetani, when freshly inoculated and sealed up in an atmosphere of hydrogen, were not destroyed, but, on the contrary, grew luxuriantly, even in the brightest sunshine. Moreover, cultures so grown were not at all diminished in virulence.

In tetanus-cultures grown in the direct rays of bright sunlight, suspended in a window but without the screen behind them, the bacilli seemed almost asporogenous. This was seen to be due to the comparatively low temperature $\left(15-22^{\circ} \mathrm{C}\right.$ ) at which they had been grown, since, on raising the temperature, spore formation immediately commenced. ${ }^{2}$

The effect of sunlight on cultures of cholera bacilli may be said to be twofold-

1. It is destructive to the bacteria on which it falls, if they be in free contact with the air.

2. It aids the growth of those bacteria on which it falls through its heating power, if the bacteria be not in free contact with the air.

With reference to the first conclusion, the destructive power of sunlight has been pointed out by so many observers that it scarcely needs confirmation. In my experiments the cultures in solid media, in which the bacteria on the surface were killed, and that series in which total destruction of the micro-organisms in very shallow liquid cultures occurred, may be quoted as additional proof of the fact.

That sunlight aids the development of those bacteria which are not freely exposed to the air is shown-

(a) By the growth which takes place during the time of exposure in liquid cultures, where the depth is greater than $2-4 \mathrm{~cm}$.

The same is true of cultures in solid media under the same conditions, with the exception that the accompanying destruction is more strictly limited to the surface, because of the limitation of movement, the bacteria remaining in situ in solid cultures; whereas in liquid media, from a variety of causes, such is not the case.

\footnotetext{
${ }^{1}$ Gaillard, "De l'Influence de la lumiere sur les micro-organismes," Lyon, 1888 ; Pansini, op. cit. ; Laurent, Ann. de l'Inst. Pusteur, Paris, 1890, vol. iv. p. 478 ; Dieudonné, op. cit. ; d'Arsonval and Charrin, Compt. rend. Soc. de biol., Paris, 1894, vol. cxviii. p. 151.

2 It may be here mentioned that, when the white sereen was placed behind the exposed cultures and the temperature thus raised, growth occurred much more quickly than when the screen was not employed.
} 
(b) By the free growth that takes places in anærobic cultures in an atmosphere of hydrogen, when exposed to the strongest sunlight.

When considering experiments made to determine the effect of direct sunlight upon freshly-inoculated cultures of ærobic microorganisms, it seems safe to assume that two processes are going on at the same time, namely, a destructive action at the surface and growth in the depths of the medium.

If the medium be deep, the growth outstrips the destruction, and, after a short time, turbidity may appear just as in cultures grown under ordinary circumstances.

On the other hand, when the depth of the liquid is very small, the destructive process is more rapid, and no turbidity is to be detected.

In those cultures which have been grown in bright sunlight the bacteria are not appreciably diminished in virulence, so that, viewing the matter of disinfection by sunlight in the light of these facts, it appears that too much reliance cannot be placed in the bactericidal action of the solar rays, even in tropical countries.

Whether it is safe to argue from these experiments that the same results follow when pools containing nitrogenous matter are infected with cholera and warmed by the sun, cannot be rashly decided. It must be remembered that in one case one is dealing not only with cholera, but with many other forms of bacterial life, while in these experiments pure cultures have been employed.

It is, however, interesting to know, when speaking of sunlight as a germicidal agent, that it is not enough to regard exposure of cultures to the sun as sufficient for the complete destruction of bacteria. It must be remembered that to attain this end it is necessary that the exposure should be in the presence of air, and, moreover, that the contact must be free; as otherwise, instead of destruction, growth may occur, and the very thing brought about which it is desired to avoid. 